\title{
Introduction: Napoleonic Governance and the Integration of Europe
}

\begin{abstract}
This study is concerned with the ways in which the present-day Netherlands and Northwest Germany were integrated into the Napoleonic Empire, by replacing local institutions and traditional governing practices with French ones. This process of running the Empire is referred to as Napoleonic governance. Traditionally, little attention was given to the dynamics of French rule in conquered Europe. Nationalistic tendencies long obstructed a neutral view of Napoleon's treatment of conquered Europe, certainly when it came to the Dutch and Northwest German regions. It was assumed French reforms were accepted unconditionally by local populations. Recent research shows that in newly acquired lands, officials often had to proceed differently. However, the northern periphery of the Napoleonic Empire is not yet fully explored. The premise of this study is that a (trans)regional perspective can lead to new interpretations. Napoleonic governance is analyzed by distinguishing between the phases of conquest, incorporation, and integration. In a broader sense, the study aims to gain a better understanding of the difficulties that have been inherent to workings of the Napoleonic Empire.
\end{abstract}

Keywords Napoleonic governance $\bullet$ Netherlands $\bullet$ Northwest Germany $\bullet$ Historiography $\bullet$ Empire-building 


\section{EMPIRE-BUILDING AND ITS LIMITS}

By 1810, the Napoleonic Empire, almost at the height of its power, encompassed much of Continental Europe. The vast European Empire was the outcome of more than a decade of French power politics. Soon after general Napoleon Bonaparte had seized power in 1799, he strove to unite Europe under the leadership of the French. Initially, he formed alliances and founded vassal states, but increasingly he sought to bind the nations of Europe to France by conquering them and transforming them into French departments. ${ }^{1}$ Napoleon continued a policy that was developed earlier by French revolutionaries. Present-day Belgium and the German territories situated on the left bank of the Rhine had already been conquered by French forces and incorporated into the French Republic. After that, large parts of Central Europe and Italy gradually followed. As his Empire grew, Bonaparte began to fantasize about a unified European entity organized according to his principles. His desire to rule from above and to destroy local diversity was a recurring element in his policy. ${ }^{2}$ Admittedly, Napoleon never had a definite masterplan for Europe, but undeniably he did start to regard uniformity as essential. ${ }^{3}$

In the North, the Kingdom of Holland and the Hanseatic cities and principalities of Northwest Germany, in 1810, were not yet incorporated into the Empire. Although they were within the Napoleonic sphere of influence, Napoleon Bonaparte long believed a certain autonomy for these regions was in his interest. Other measures, like military pressure and invoking coups d'état, were considered sufficient. Nevertheless, driven by ambitions and growing fears of British interventions at the North Sea Coast, he eventually put an end to the Dutch state, Hanseatic city-states, and many German principalities in Northwest Germany. Soon after, Catalonia and the Illyrian Provinces in the northern Balkans, would also, albeit briefly, be incorporated, expanding the French Empire to its maximum territorial extent, comprising no less than 130 departments.

Throughout his reign, Napoleon's reforms focused on the construction of a centralized bureaucratic state, characterized by uniform and rational

\footnotetext{
${ }^{1}$ Jean Tulard, 'Les politiques européennes de Napoléon', in: T. Lentz ed., Napoléon et l'Europe (Paris 2005) 427-429.

${ }^{2}$ Annie Jourdan, L'empire de Napoléon (Paris 2000) 125.

${ }^{3}$ Thierry Lentz, 'Imperial France in 1808 and beyond', in: M. Broers, P. Hicks and A. Guimerá ed., The Napoleonic empire and the new European political culture (Basingstoke 2012) 34-35.
} 
structures in the French style. On the one hand, it was simply efficient for the governability of the Empire to introduce French institutions and personnel in the newly acquired territories. ${ }^{4}$ On the other hand, many French officials were convinced that they were the sole driving force behind the 'modernization' (understood as 'Francization') of Europe. ${ }^{5}$ Certainly, hardliners among them felt contempt for local traditions. The intended export of the French model was without doubt partly an expression of feelings of cultural superiority. ${ }^{6}$ However, it was tremendously difficult for the Napoleonic government to immediately create support for the formation of a new modern state without taking into account local circumstances and wishes. Although scholars disagree over the extent to which the central government was willing to compromise, for the French officials 'the price of collaboration was', in the words of historian Stuart Woolf, 'the acceptance of limits'?

\section{Napoleonic Governance in the Regions}

This study discusses the ways in which Napoleon tried to integrate the present-day Netherlands and Northwest Germany into the French Empire, by replacing local institutions and traditional governing practices with French ones. More specifically, it deals with the imposition of a French system of governance on the conquered Dutch and German territories. By Napoleonic governance I do not narrowly refer to the administrative structures of the Empire, but more broadly the process of governing this entity - or less abstractly: the ways in which the expanding Napoleonic Empire was run, not merely at the top, but also in the regions. Recent scholarship increasingly emphasizes that governance goes beyond the authority of the central state, and acknowledges the diversity of governing practices in past and present. To quote scholar Mark Bevir: 'Governance is explained by the narratives that the relevant actors first inherit as historical

${ }^{4}$ D. G. Wright, Napoleon and Europe (Harlow 1984) 65-67.

${ }^{5}$ Stuart Woolf, 'Napoleon and Europe revisited', Modern \& Contemporary France 8 (2000) 471. https://doi.org/10.1080/713685288

${ }^{6}$ Michael Broers, 'Napoleon, Charlemagne, and Lotharingia: Acculturation and the boundaries of Napoleonic Europe', The Historical Journal 44 (2001) 178. https://www. jstor.org/stable/3133664; Aurélien Lignereux, L'Empire des Français: 1799-1815 (Paris 2012).

${ }^{7}$ Stuart Woolf, Napoleon's integration of Europe (London and New York 1991) 115. 
traditions and then revise in response to dilemmas', which, according to Bevir, gives governance a greater explanatory power than other terms. ${ }^{8}$

This approach sets governance apart from regime-a term that is frequently used when referring to the rule of Napoleon and his collaborators. I have chosen Napoleonic governance over Napoleonic regime, since governance explicitly sees the running of a state as a dynamic process, with multiple actors, and not as a somewhat static set of regulations dictated by an omnipotent leader - the latter being the more institutional approach stressing the primacy of the central government. Moreover, in daily speech, the term regime carries a negative connotation, implying a position in scholarly debates on the nature of Napoleonic rule. Such an a priori assumption might yield biased results. Instead of stressing the, unquestionably very authoritarian, leadership of Napoleon Bonaparte, I focus on lesser-known individuals who were tasked with empire-building in the regions. Undeniably, there has been large-scale suffering because of Napoleonic measures and exploitation; but my primary objective is analyzing how those measures reached the regions, were interpreted there, and interacted with existing governing practices.

Finally, using the governance concept has a practical reason. Working in four languages brings the problem of false friends. 'Administration/ administratie' and 'gouvernement/government' have different meanings in Dutch, English, French and German. Nor do these fully correspond to Germanic equivalents like 'Regierung/regering', 'Verwaltung', or 'bestuur'. And the concept of police/politie/Polizey could also be included, since it was not until the Napoleonic period that these concepts gradually became distinct from each other.9 'Governance' circumvents such translation difficulties.

Territories conquered by French were faced with the introduction of an extremely hierarchical and top-down state model. Yet, as Michael Broers has argued, the Napoleonic Empire was actually centralized like a 'spider's web'. There were five main lines along which the central government in Paris attempted to assert its power over the farthest corners of the Empire: the Ministries of the Interior, General Police, War, Finance, and Justice. These branches of government were firmly separated; each branch had its

\footnotetext{
${ }^{8}$ Mark Bevir, A theory of governance (Berkeley 2013) 1-5.

${ }^{9}$ Igor Moullier, 'Police et politique de la ville sous Napoléon', Revue d'bistoire moderne et contemporaine (2007) 117-139. https://doi.org/10.3917/rhmc.542.0117
} 
own competencies, spheres of action, and mechanisms of self-regulation. ${ }^{10}$ In this study, I explore a significant line from Paris: the prefectoral system. This branch was part of the Ministry of the Interior and, in theory, the vehicle of choice for state power. So-called préfets (prefects) were the heads of a department, the main administrative units within the French state, and delegated tasks to the sous-préfets (subprefects). Conversely, local information had to come back to the ministries fast; the prefectoral system has been called 'the interface between a centralized state and a local society'. ${ }^{11}$

Complicating matters, Napoleonic officials in many incorporated territories often had to deal with an intermediary governance body set up by the French government, for instance in Hamburg and Amsterdam. Such intermediary gouvernements généraux had an ambiguous place within the structure of the Empire.

Emphasis on these specific aspects of the functioning of the Napoleonic state also relates to current discussions on the nature of Napoleonic interventions in Europe. Regarding the French treatment of the incorporated lands and subject states, there are essentially two opposing interpretations. Historians either stress, often depending on their geographical area of study, the positive reforming influences of Napoleon's system of governance, or underline the negative effects of severe exploitation and harsh domination. Geoffrey Ellis has summed it up as the 'continuing debates of the kicks and kindnesses of French rule'. ${ }^{12}$

For instance, Alexander Grab has stressed that Napoleon was more than an exploiting dictator and his reform programs left a great, often constructive impact on Europe, especially the export of the modern central state. ${ }^{13}$ Similarly, Brendan Simms has pointed out positive consequences of the Napoleonic experience. Napoleonic officials in Europe 'created some of the preconditions for a capitalist, legally equal, religiously

\footnotetext{
${ }^{10}$ Michael Broers, 'Pride and prejudice: The Napoleonic Empire through the eyes of its rulers', in: U. Planert ed., Napoleon's empire: European politics in global perspective (Basingstoke 2016) 309; Michael Broers, Europe under Napoleon, 1799-1815 (London and New York 1996) 54-55.

${ }^{11}$ Gavin Daly, Inside Napoleonic France. State and society in Rouen, 1800-1815 (Aldershot 2001) 64 .

${ }^{12}$ Geoffrey Ellis, The Napoleonic empire (2nd ed; Basingstoke 2003) 93-94. For the German case see T. C. W. Blanning, 'The French revolution and the modernization of Germany', Central European History 22 (1989) 109-129. https://doi.org/10.1017/ S0008938900011468

${ }^{13}$ Alexander Grab, Napoleon and the transformation of Europe (Basingstoke 2003) 205-206.
} 
tolerant and rationally governed bourgeois society', a requisite for the formation of the nation-state. ${ }^{14}$ Michael Broers, however, has underscored the harshness and rigidity of Napoleonic personnel. Not denying the pragmatism (or even reasonableness) of individual Napoleonic state servants, according to Broers it was with the repressive forces, such as military and police, that power really lay. These men were hardly concerned with appeasing and enlightening the newly conquered subjects-certainly not during the closing years of the Empire. ${ }^{15}$ And Pierre Horn, who has more recently investigated the cultural distance between French authorities and the populations of East Belgium, West Rhineland and Luxembourg, points to increasing exhaustion of the pays réunies and economic crises (such as poor harvests, inflation, taxation, and declining international trade). Horn's study suggests that many officials may have been willing to listen to local concerns, but could not thwart negative measures from the imperial core. ${ }^{16}$

More historians could be quoted here-but the main point is that the perspective of researchers (top-down or bottom-up, center or periphery) plays a role in their position in the debate on 'the kicks and kindnesses of French rule', and thereby their evaluation of Napoleonic governance. The imperial authorities in Paris are often taken as the starting point for a study, not actors at a lower level in the hierarchy. But as Stuart Woolf has argued, Napoleonic representatives in the regions, such as prefects and their collaborators were 'closer to the ground' than other authorities. Due to the range of their responsibilities they provide good information on the local responses to French governance. Given the wide powers of the prefects and their role as the 'eyes and ears' of the central government, their archives harbor a wealth of information about local reactions to centralist measures, which unfortunately are not often used by historians. ${ }^{17}$

\footnotetext{
${ }^{14}$ Brendan Simms, The struggle for mastery in Germany, 1779-1850 (Basingstoke 1998) 88.

${ }^{15}$ Michael Broers, 'Cultural imperialism in a European context? Political culture and cultural politics in Napoleonic Italy', Past and Present (2001) 152-180. https://doi. org/10.1093/past/170.1.152; Broers, Europe under Napoleon, 1799-1815, 67.

${ }^{16}$ Pierre Horn, Le défi de l'enracinement napoléonien entre Rhin et Meuse 1810-1814: l'opinion publique dans les départements de la Roër, de l'Ourthe, des Forêts et de la Moselle (Berlin 2017).

${ }^{17}$ Woolf, 'Napoleon and Europe revisited', 474.
} 


\section{Historiography on Napoleon and Europe}

Napoleonic governance, or administration in general for that matter, has never really captured the hearts and minds of historians the way, for instance, statesmen and generals have done. Compared to other aspects of Napoleonic history, there is little literature on the European dimension of Napoleonic governance. Up until the late 1980s, historiography on the Napoleonic Empire was dominated by military history, or by biographical studies of Bonaparte. Whether past historians criticized or admired Napoleon, many emphasized the vision of one man. Moreover, many publications were rather francocentric, assuming that French restructurings were accepted unconditionally by local populations. Little attention was given to the dynamics of French rule in conquered Europe. Since the 1990s, however, there has been a shift toward studies focusing on coreperiphery relations and on the dynamics of integration into the Empire. It has become clear that there, French had to act differently, often more cautiously. ${ }^{18}$ By exploring the impact of Napoleonic rule in Europe, scholars reveal responses of the Europeans to French imperialism.

Stuart Woolf's pioneering study Napoleon's integration of Europe or Napoléon et la conquête de l'Europe (1990/1991)—note the differences in title-is often cited as one of the first studies that examined the fundamental problems with Napoleonic attempts to force the heterogeneous European societies into a single mold. ${ }^{19}$ It was intended to encourage historians to breach away from the excessive attention given to Bonaparte and metropolitan France. Woolf argued that the Napoleonic Empire could and should be examined by looking beyond the Emperor. Instead, integration attempts are explored by looking both through the eyes of the central government and at responses of local communities to Napoleonic measures. Woolf encouraged European historians to look beyond their national borders; regretting the 'hegemony [of] deep-rooted political and national imperatives of European historiography'. ${ }^{20}$

Historian Isser Woloch also contributed to a different understanding of governance in the Napoleonic Empire, by moving the attention given to

\footnotetext{
${ }^{18}$ Steven Englund, 'Monstre sacré: The question of cultural imperialism and the Napoleonic Empire', The Historical Journal 51 (2008) 216-217. https://doi.org/10.1017/ S0018246X07006656

${ }^{19}$ Stuart Woolf, Napoléon et la conquête de l'Europe (Paris 1990); Woolf, Napoleon's integration of Europe.

${ }^{20}$ Woolf, Napoleon's integration of Europe, 477.
} 
the Emperor, toward the men in the imperial entourage. Those have been influential and not necessarily staunch supporters of Napoleon. ${ }^{21}$ And in The New Regime, Woloch calls for a shift from a 'top-down' to a 'bottomup' view on the French state. Woloch questions the extent to which the state could impose its will on local communities. By studying state formation from the bottom up, Woloch argues that Napoleon (and his Revolutionary predecessors) succeeded mainly by pragmatism and negotiation-a legacy he left to the Restoration monarchs. ${ }^{22}$

Likewise, Oxford historian Michael Broers has examined (dis)continuity in his influential studies Europe under Napoleon (1996) and Europe after Napoleon (1996). ${ }^{23}$ The Emperor was well aware of diversity in Europe, and, Broers argues, this understanding entailed a form of cultural imperialism. ${ }^{24}$ Broers has suggested that the Napoleonic Empire consisted of a well-integrated 'inner empire', an intermediate zone, and an 'outer empire' where Napoleon's rule was constantly contested. Broers argues that many of the incorporated territories were, in fact, better integrated into the Empire than large parts of the French rural areas. ${ }^{25}$

Many scholars have embraced the 'New Napoleonic History'. Geoffrey Ellis, Annie Jourdan, Alexander Grab, and Aurélien Lignereux (to name but a few) have written well-documented, studies on the Empire from a European viewpoint. ${ }^{26}$ However, in monographs and conference volumes, the imperial North Sea coast and its hinterland are not well represented, certainly not when it comes to Napoleonic governance. Partly this can be contributed to historians' scant knowledge of Dutch or German, but even in German-language and Dutch-language scholarship, relatively few studies have been published on the period of French rule. Long, both in Northwest Germany and in the Netherlands, the influence of traditional anti-French historiography was significant. The period was seen as an interlude, which at most would have served as the starting point of a modern national

\footnotetext{
${ }^{21}$ Isser Woloch, Napoleon and his collaborators: The making of a dictatorship (New York 2001).

${ }^{22}$ Isser Woloch, The new regime. Transformations of the French civic order, 1789-1820s (New York 1995).

${ }^{23}$ Broers, Europe under Napoleon, 1799-1815, 4; Michael Broers, Europe after Napoleon. Revolution, reaction, and romanticism, 1814-1848 (Manchester 1996).

${ }^{24}$ Broers, 'Cultural imperialism'.

${ }^{25}$ Broers, 'Napoleon, Charlemagne, and Lotharingia'.

${ }^{26}$ Ellis, The Napoleonic empire; Jourdan, L'empire de Napoléon; Grab, Napoleon and the transformation of Europe; Lignereux, L'Empire des Français.
} 
consciousness. This characterization is a legacy of nineteenth-century historians who emphasized the foreignness of the Napoleonic period.

\section{German Historiography}

In Germany, the creation of a unified state under Prussian leadership intensified the neglect of the Napoleonic period. The creations of federal states under Napoleon (the so-called Confederation of the Rhine) and after Napoleon (the German Confederation) were considered historical 'errors' that did not fit national history. ${ }^{27}$ However, more and more historians aim to approach the period more neutrally, recognizing the diversity of German experiences. ${ }^{28}$ When it comes to a possible reappraisal of the Napoleonic era in Northwest Germany, the main difficulty has always been the territorial and geopolitical reordering, contributing to a historiographical fragmentation (see also the problems with archival sources, below). There has been little institutional continuity before and after the years 1806-1814, therefore studies on the Revolutionary and Napoleonic era in North(west) Germany tend to focus on specific towns or regions.

In the early 1970s, Antoinette Joulia wrote a well-documented doctoral thesis on the Ems-Supérieur department and several articles on the Hanseatic departments. ${ }^{29}$ Concurrently, Jean Vidalenc, who primarily worked on Old France, published two articles on Napoleonic governance in the Hanseatic departments. ${ }^{30}$ In 1981, the first edition of Elisabeth Fehrenbach's Vom Ancien Régime zum Wiener Kongress was published, presenting a thorough and concise analysis of the Revolutionary Period in Germany. She shifted emphasis from Prussia to the Confederacy of the

\footnotetext{
${ }^{27}$ Andreas Fahrmeier, 'Centralisation versus particularism in the "Third Germany", in: M. Rowe ed., Collaboration and resistance in Napoleonic Europe. State-formation in an age of upheaval, c. 1800-1815 (Basingstoke 2003) 107-120.

${ }^{28}$ For example, Alan Forrest and Peter H. Wilson ed., The bee and the eagle. Napoleonic France and the end of the holy roman empire, 1806 (Basingstoke 2008).

${ }^{29}$ Antoinette Joulia, 'Les institutions administratives des départements hanséatiques', Revue d'histoire moderne et contemporaine 17 (1970) 880-892; Antoinette Joulia, Le département de l'Ems-Supérieur 1810-1813. Étude de la mise en place du système administratif en milieu allemand (Ph.D. thesis Strassbourg 1972); Antoinette Joulia, 'Ein französischer Verwaltungsbezirk in Deutschland: Das Oberemsdepartement (1810-1813)', Osnabrücker Mitteilungen 80 (1973) 21-102.

${ }^{30}$ Jean Vidalenc, 'Les notables des départements hanséatiques', Revue d'histoire moderne et contemporaine 17 (1970) 777-794; Jean Vidalenc, 'Les 'départements hanséatiques' et l'administration napoléonienne’, Francia l (1973) 414-450.
} 
Rhine, with some coverage of Northwest German areas outside the Confederacy. The book also explored the study of cultural transfer in the Revolutionary and Napoleonic period-an early transnational approach that received an impetus, late twentieth century. ${ }^{31}$ Concurrently, Thomas Nipperdey published his Deutsche Geschichte 1800-1866 (1983) in which Napoleon' impact received serious attention, starting with the sentence: 'Am Anfang war Napoleon' ('In the beginning was Napoleon'). ${ }^{32}$

From an urban-historical perspective, in his study Hamburg im Zeitalter der Französischen Revolution und Napoleons, Burghart Schmidt examined many aspects of Hamburg in the time of the French Revolution and Napoleon. He wanted to go beyond a simplistic interpretation GermanFrench relations, stating that previous historians were too much influenced by national(ist) interpretations. Schmidt wanted to distance himself from the strong distinction between 'victims' and 'oppressors' that is present in traditional historiography. Schmidt acknowledges that Germans suffered under many harsh measures taken by the French authorities, but he also points to the positive effects of modernization, and to cooperation. ${ }^{33}$

Of great interest is the work of Katherine Aaslestad on Northwest German culture in the Napoleonic period, with an emphasis on the citystate Hamburg, specifically its impact on local, regional and national identity formation. In her book Place and politics, Aaslestad investigates transformations in civic culture and republicanism, against the background of socio-economic changes. In the Napoleonic period, local identities remained important, but also regional ones emerged, within the context of German national thought. ${ }^{34}$ Her research provides insights into how local populations responded to Napoleonic governance, in a time of

\footnotetext{
${ }^{31}$ Elisabeth Fehrenbach, Vom Ancien Régime zum Wiener Kongress (4th ed.; München 2001); Hans-Jürgen Lüsebrink and Rolf Reichardt ed., Kulturtransfer im Epochenumbruch: Frankreich-Deutschland 1770 bis 1815 (Leipzig 1997).

${ }^{32}$ Thomas Nipperdey, Deutsche Geschichte 1800-1866: Bürgerwelt und starker Staat (München 1983) 11.

${ }^{33}$ Burghart Schmidt, Hamburg im Zeitalter der Französischen Revolution und Napoleons (1789-1813) (Hamburg 1998) 741-743.

${ }^{34}$ Katherine Aaslestad, Place and politics: Local identity, civic culture and German nationalism in North Germany during the Revolutionary Era (Leiden 2005) 10-11; Katherine Aaslestad and Karen Hagemann, '1806 and its aftermath: Revisiting the period of the Napoleonic Wars in German Central European historiography', Central European History 39 (2006) 547-579.
} 
economic crisis and military exploitation. Aaslestad argues that reactions to Napoleon's measures were, first and foremost, motivated by local circumstances. State interventions actually 'generated new forms of regionalism', such as a broader Hanseatic identity, simultaneously such regional tendencies would inspire nineteenth-century national thinkers. ${ }^{35}$

Lastly, Helmut Stubbe da Luz, an expert on civilian-military relations, has worked on occupation, during the Napoleonic period in Northwest Germany, but also in a broader sense. ${ }^{36}$ Stubbe da Luz has extensively published on the three Hanseatic departments as a whole. His 'Franzosenzeit' in Norddeutschland is one of the few monographs on the matter, and it devotes ample attention to Napoleonic governance. ${ }^{37}$ Importantly, in his edited volume Statthalterregimes, Stubbe da Luz initiated a comparison of different intermediary governments in Italy, the Netherlands and Germany (the gouvernements généraux) in Napoleonic Europe. Basing himself on several case studies written by international historians, Stubbe da Luz analyzes the diffusion of the gouvernement général as an instrument of integration, though he prefers the term Besetzung (occupation) as the lens to study cases through. ${ }^{38}$

\section{Dutch Historiography}

There are notable differences and similarities between German and Dutch historiography on the years of Napoleon's rule. An obvious difference is, of course, the continuity between the Dutch departments and the later Kingdom of the Netherlands, and Belgium, opposed to the discontinuity in Germany. Virtually all Dutch departments were converted into provinces and, apart from the rupture between North and South in 1830, state borders changed little. This stability facilitated the emergence of a national historiography. Strikingly similar to Germany (taking Prussia as pars pro toto), the establishment of the new monarchy in 1814-1815 was

\footnotetext{
${ }^{35}$ Katherine Aaslestad, 'Paying for war: Experiences of Napoleonic rule in the Hanseatic Cities', Central European History 39 (2006) 675. https://doi.org/10.1017/ S0008938906000215

${ }^{36}$ Helmut Stubbe da Luz, Okkupanten und Okkupierte: Napoleons Statthalterregimes in den Hansestädten (6 vols.) 2004-2013 (München 2004).

${ }^{37}$ Helmut Stubbe da Luz, 'Franzosenzeit' in Norddeutschland (1803-1814). Napoleons Hanseatische Departements (Bremen 2003).

${ }^{38}$ Helmut Stubbe da Luz ed., Statthalterregimes-Napoleons Generalgouvernements in Italien, Holland und Deutschland (1808-1814) (Hamburg 2016).
} 
accompanied by a process of collective amnesia. Only events that could be interpreted as a prelude to the nineteenth-century nation-state with the House of Orange-Nassau were remembered. The Napoleonic period did not ideologically fit in with the newly constructed Dutch monarchy. Historian Matthijs Lok has made clear how from 1813 onward, the Napoleonic period was simply ignored. This was somewhat more straightforward than in Germany since, in contrast to Germany, there was a single monarch, William I, whose government pursued an unofficial policy of 'forgetting'. Many of the actions during the Napoleonic period were blamed on the French, and the contributions of the Dutch forgotten or glossed over. ${ }^{39}$

Due to this historical amnesia, until the twenty-first century, there were only two monographs on the Napoleonic period in the Netherlands. Firstly, Johanna Naber's well-received book Overheersching en vrijwording (first edition 1909; revised edition 1913) which offered a nuanced view of the period. ${ }^{40}$ Naber carefully investigated many aspects of the years of integration and the end of Napoleon's rule in the Netherlands. A few years later, Inlijving en opstand (1913) was published by Herman Theodoor Colenbrander. According to Colenbrander the Dutch under Napoleon had been characterized by a state of passivity. Colenbrander, a nationally orientated historian, focused on the House of Orange and its connections with Dutch history. The Napoleonic period was interpreted as merely a prologue to the establishment of the Dutch nation-state. ${ }^{41}$ Colenbrander seems to have based significant parts of his book on Overheersching en vrijwording, without really acknowledging the work of Naber. Colenbrander's book was also less thorough, but as a Leiden Professor his prestige was greater than the women's rights activist Johanna Naber, therefore his evaluation of the Napoleonic period in the Netherlands would long be influential. ${ }^{42}$

The 1960s and 1970s saw a wave of new research into the years of Revolution and, to a much lesser extent, the Napoleonic period in the

\footnotetext{
${ }^{39}$ Matthijs Lok, Windvanen: Napoleontische bestuurders in de Nederlandse en Franse restauratie (1813-1820) (Amsterdam 2009) 166-167.

${ }^{40}$ Johanna W. A. Naber, Overheersching en vrijwording: geschiedenis van Nederland tijdens de inlijving bij Frankrijk, juli 1810-november 1813 (Haarlem 1913).

${ }^{41}$ H. T. Colenbrander, Inlijving en opstand (Amsterdam 1913) 127.

${ }^{42}$ Maria Grever, 'Naber, Johanna Wilhelmina Antoinette', Digitaal Vrouwenlexicon van Nederland (2015). http://resources.huygens.knaw.nl/vrouwenlexicon/lemmata/ data/Naber
} 
Netherlands. For instance, studies by Robert Palmer, Simon Schama, and C. H. E. de Wit-who all agreed the French model during the long Dutch Age of Revolution (c. 1780-1815) was less dominant than had been portrayed. ${ }^{43}$ In the 1980s, new research focused mainly on late-eighteenthcentury political thought: new research by historians like Niek van Sas, Wijnand Mijnhardt, Renger de Bruin, Stephan Klein, and Joost Rosendaal cleared the way for new scholars of Napoleonic history to re-evaluate the position of the Dutch within the Napoleonic Empire. ${ }^{44}$

Since 2000 more serious attention has been given to Napoleonic Netherlands. Johan Joor, in his De Adelaar en het Lam (The Eagle and the Lamb), made clear that the Dutch contested Napoleonic rule. Joor showed that in every corner of the Kingdom of Holland (1806-1810), and later the Dutch imperial departments, inhabitants challenged Napoleonic measures. Dutch uprisings were primarily local in nature, but such protests successfully destabilized the state. According to Joor, previous historians neglected these struggles because they only looked for conflicts that were explicitly pro-Orange and anti-French. ${ }^{45}$ Literary scholar Lotte Jensen works on Dutch resistance literature, and its impact on Dutch national thought. According Jensen, certain forms of protest or opposition did contribute to national feelings under Napoleon. She states that from a cultural and literary viewpoint, protest was embedded in a national context. ${ }^{46}$

Bart Verheijen's book Nederland onder Napoleon (The Netherlands under Napoleon) echoes the title of the earlier-mentioned work by Michael Broers. Verheijen studies political-cultural identity formation, and has shown that Frenchmen not necessarily worked together in good harmony, and, conversely, Dutchmen were certainly not all preoccupied with

${ }^{43}$ R. R. Palmer, 'Much in little: The Dutch Revolution of 1795', The Journal of Modern History 26 (1954) 15-35. C. H. E. de Wit, De strijd tussen aristocratie en democratie in Nederland, 1780-1848: kritisch onderzoek van een historisch beeld en herwaardering van een periode (Heerlen 1965). Simon Schama, Patriotten en bevrijders: revolutie in de Noordelijke Nederlanden, 1780-1813 (Amsterdam 1989).

${ }^{44}$ For example, N. C. F. van Sas, De metamorfose van Nederland. Van oude orde naar moderniteit, 1750-1900 (Amsterdam 2004).

${ }^{45}$ Johan Joor, De Adelaar en het Lam: onrust, opruiing en onwilligheid in Nederland ten tijde van het Koninkrijk Holland en de inlijving bij het Franse keizerrijk (1806-1813) (Amsterdam 2000).

${ }^{46}$ Lotte Jensen, Verzet tegen Napoleon (Nijmegen 2013). 
proto-nationalism. ${ }^{47}$ By taking political debate as a point of departure, Verheijen deepens the insights of Johan Joor, as well as those of Lotte Jensen: for instance, he links regional rural upheaval concerning national taxes with national thought of writers and poets.

Many aspects of the Dutch Napoleonic experience deserve further attention. Joor, Jensen, and Verheijen have given valuables insights into popular protest, state repression, identity formation and public debate, yet a critical study on how the Empire was constructed and run is lacking. ${ }^{48}$ To quote Matthijs Lok: 'A study of the administration of the Dutch provinces as part of the huge Napoleonic empire, which integrates the Dutch case in international research on this topic and does not regard the years 1810-1813 from the perspective of its outcome, is therefore urgently needed'. ${ }^{49}$ This can also be said for the even lesser studied Hanseatic departments.

\section{Transregional Perspectives}

As noted above, the history of the area under scrutiny was long written from nationally defined viewpoints, sharply discriminating between presumed 'oppressors' and 'victims'. Consequently, neighboring Netherlands and Northwest Germany have often been studied in isolation. Changing spatial frameworks can however lead to new insights, both transnational and transregional, thus questioning the nation-state as a unit of analysis. ${ }^{50}$ Particularly, a transregional study of Napoleonic governance can be relevant. Until recent, there have been few studies concerning its reception at lower levels, certainly not in conquered Europe. Yet the scope of Napoleon's centralist reforms can perhaps best be measured regionally, since 'Paris' specifically wanted to destroy traditional diversity. Serious

\footnotetext{
${ }^{47}$ Bart Verheijen, Nederland onder Napoleon: partijstrijd en natievorming 1801-1813 (Nijmegen 2017).

${ }^{48} \mathrm{An}$ indispensible overview of institutional changes, literature and archives is Joke Roelevink, Onderzoeksgids bestuur en administratie van de Bataafs-Franse tijd, 1795-1813 (Den Haag 2012). http://resources.huygens.knaw.nl/bataafsfransetijd

${ }^{49}$ Matthijs Lok, 'The bicentennial of '1813-1815' and national history writing: Remarks on a new consensus', BMGN-Low Countries Historical Review 130 (2015) 118. https:// doi.org/10.18352/bmgn-lchr.10148

${ }^{50}$ Eric Storm, 'The spatial turn and the history of nationalism. Nationalism between regionalism and transnational approaches', in: S. Berger and E. Storm ed., Writing the history of nationalism (London 2019) 215-238.
} 
clashes must have occurred between the pursuit of Napoleonic governance and the wishes of communities. Fortunately, fresh studies on state-building from the bottom-up provide new images of Napoleonic rule in the regions.

Historians increasingly pay attention to alternative regional narratives, such as Katherine Aaslestad and Michael Rowe, who stress the importance of regional approaches to nuance the one-sided image of Napoleonic times as only a period of burgeoning national consciousness. Transregional is Aaslestad's 'Lost neutrality and economic warfare', which treats the Napoleonic Netherlands, Northwest Germany, and Southern Denmark as a whole. She argues that around 1800, North Europeans were not unfamiliar with (economic) warfare and exploitative occupations, but the scale and scope were unprecedented. In combination with the legacy of Napoleonic governance, such dramatic events fostered regionalism. ${ }^{51}$

This goes for many regions. For instance, Michael Rowe has examined the connections between regional and national identities in the German Rhineland. Rowe has shown how a regional identity did not form in opposition to the French, but how 'Rhenishness', primarily after the years of Napoleonic rule, had a problematic relationship with Prussian concepts of German identity. The Rhenish elites used the Napoleonic framework to secure their position, taking advantage of the problematic nature of Napoleonic governance. ${ }^{52}$ Similarly, Brecht Deseure and Diederik Smit have demonstrated for post-Napoleonic Low Countries how the Restoration government took regional variations into account, for example, by reintroducing the provinces. For the new rulers, the appropriation of early modern institutions and sentiments was a key instrument in the creation of a new unified state, as long as regional differences were acknowledged. ${ }^{53}$

Lacunae in national or regional historiographies should also be considered in relation to the availability and completeness of regional archival material. In the Netherlands, thanks to the relative institutional continuity

${ }^{51}$ Katherine Aaslestad, 'Lost neutrality and economic warfare. Napoleonic warfare in Northern Europe, 1795-1815', in: R. Chickering and S. Förster ed., War in an age of revolution, 1775-1815 (Cambridge 2010) 394.

${ }^{52}$ Michael Rowe, 'Between Empire and home town: Napoleonic rule on the Rhine, 1799-1814', The Historical Journal 42 (1999) 643-674. https://doi.org/10.1017/ S0018246X9900850X

${ }^{53}$ Brecht Deseure and Diederik Smit, 'Pre-revolutionary provinces in a post-Napoleonic state', BMGN-Low Countries Historical Review 133 (2018) 98-121. https://doi. org/10.18352/bmgn-lchr.10589 
between the Napoleonic departments and the current Dutch provinces, most historical official records are well preserved in national, provincial, and regional archives. ${ }^{54}$ In contrast, continuous redrawing of Northwest German borders dispersed regional archival sources. Regrettably, the German situation is also complicated because of twentieth-century war damages. The archives of the Ems-Oriental department are in Aurich, but unfortunately incomplete. The well-preserved records of the EmsSupérieur department are in Osnabrück. Since the department of Bouchesdu-Weser was split in 1815 between Hannover and Oldenburg, its archives are divided between Bremen and Oldenburg. Sadly, Bouches-de-l'Elbe's archive was damaged in 1942 due to Second World War bombings. Most of the Lippe department's archival material can be consulted in Münster. ${ }^{55}$

In view of the limitations of this study, use has been made mainly of secondary literature, published sources, and a limited selection of archival material, such as correspondence between officials (regional and local), formal reports, memoranda, newspapers, and memoires. Given the fragmentation of German source material, the analysis of the German departments is, in comparison to the Dutch departments, relatively more dependent on literature and published source material.

\section{Questions of Definition}

This study is concerned with the 13 imperial departments which nowadays are part of the Netherlands and Germany and were integrated in 1810-1811. I have tried to transcend national histories by looking at the French departments in the present-day Netherlands and Northwest Germany in conjunction-territories which were referred to as the départements de la Hollande and the départements (b)anséatiques, respectively. Unfortunately, these terms can be confusing. Napoleonic plans to integrate both areas entailed the (re)definition of Dutch and German territories. Officials in Paris not seldom had a hard time distinguishing between the two regions; consequently, even some contemporary historians

\footnotetext{
${ }^{54}$ See https://www.archieven.nl/

${ }^{55}$ See Archive in Nordrhein-Westfalen, https://www.archive.nrw.de/; Archive in Niedersachsen und Bremen, https://www.arcinsys.niedersachsen.de/; Staatsarchiv Hamburg, https://www.hamburg.de/staatsarchiv
} 
accidentally mix up the two areas. Vague distinctions between 'Dutch' and 'German' complicate the evaluation of Napoleonic governance.

Administratively, the government in Paris discriminated between the departments of Hollande (which corresponded with the Gouvernement général of Charles-François Lebrun in Amsterdam), the Hanseatic departments (supervised by General-Governor Davout in Hamburg), and three Dutch and German departments that did not fall under the authority of Amsterdam or Hamburg (Map 1.1).

Not all territories part of the départements de la Hollande were actually Dutch. Ems-Oriental (the present-day region of Ostfriesland) was a former Prussian province that had been incorporated into the Kingdom of Holland in 1807. Nevertheless, this 'Dutch' department fell under the Imperial Court in Hamburg. Furthermore, the lands that would later make up the Lippe department were initially part of three adjacent Dutch departments, thus part of the départements de la Hollande. But resistance from the local elite in Münster led to the creation of a separate German-speaking Lippe department, not under the supervision of the French in Amsterdam or Hamburg (more on this in Chap. 5). Nevertheless, some actors within the Empire (for instance, the gendarmerie, and to a certain extent the

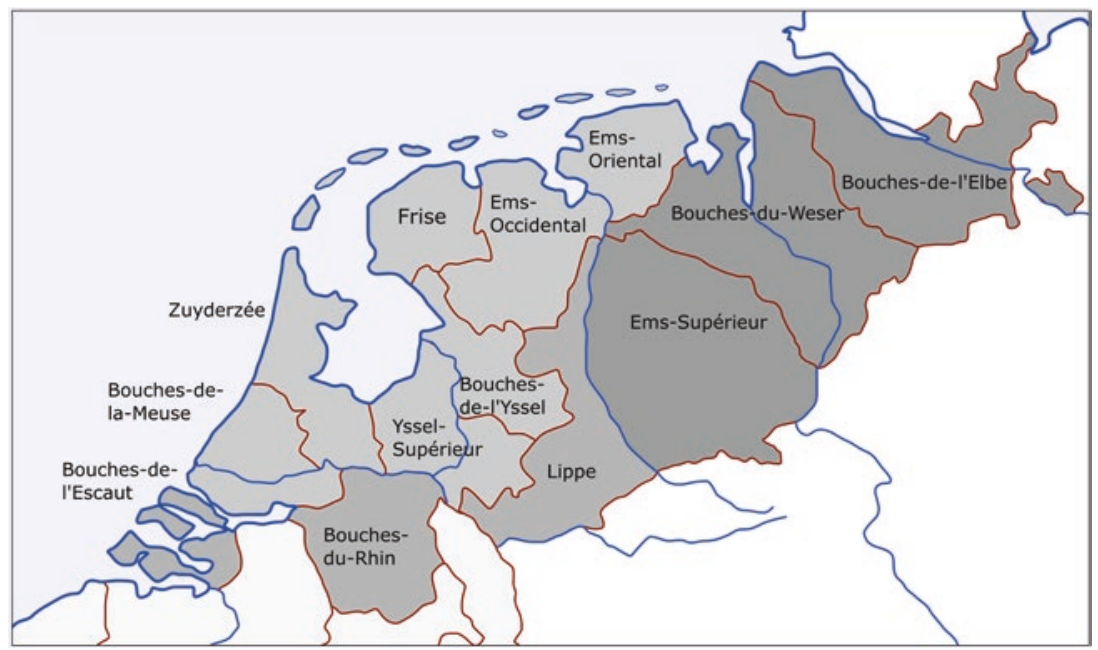

Map 1.1 Administrative division of the Dutch and Northwest German departments 
intermediary government in Amsterdam) treated Lippe as part of 'Holland', and sometimes it was viewed as 'Hanseatic'. Lippe can also be seen as an extension of the bordering departments of the Rhineland. For instance, it fell under the Imperial Court in Liège, and not the one in Hamburg.

Conversely, some parts belonging to the former Dutch Republic became an integral part of the Empire. The departments south of the Rhine-Bouches-de-l'Escaut (formerly the Dutch province of Zeeland) and Bouches-du-Rhin (Dutch Noord-Brabant) were not qualified as Dutch. The district of Breda was even merged with the existing Belgian department of Deux-Nèthes, probably due to its strategic value between the estuaries of the rivers Scheldt and Meuse. ${ }^{56}$ In official discourse, the French presented the river Rhine as their natural border, therefore in the eyes of the Ministry of the Interior, these former Dutch territories were not part of 'Holland'. In brief, ad hoc decisions based on cultural-linguistic aspects on the one hand, and pragmatism, on the other hand, redrew subnational borders in a complicated manner.

Given these imprecise definitions, a distinction is made between 'German' and 'Dutch' departments (Map 1.2), based on various considerations. Firstly, as a matter of convenience, 'Dutch departments' are defined as the departments that formerly belonged to the Dutch Republic, were predominantly Dutch-speaking and would later form the present-day Netherlands. '(Northwest) German departments' are defined as the largely German-speaking lands, including Lippe and Ems-Oriental/Ostfriesland, which formerly belonged to the Holy Roman Empire and today are part of Niedersachsen or Nordrhein-Westfalen. Secondly, when I refer to actions of the intermediary governments in Amsterdam or Hamburg these concern, of course, specifically the departments under their respective jurisdictions. Therefore, when interpreting French official documents of the time, it should be borne in mind that Hollande denotes the seven departments supervised by General-Governor Lebrun, and départements (b)anséatiques usually refers to the three departments which GeneralGovernor Davout oversaw from Hamburg.

Another question of definition concerns the key terms 'conquest', 'incorporation', and 'integration'. In the past, the Napoleonic period in the Netherlands and Northwest German has often been referred to simply

\footnotetext{
${ }^{56}$ Since the district of Breda was added to the department of Deux-Nèthes, it is excluded in the present study.
} 


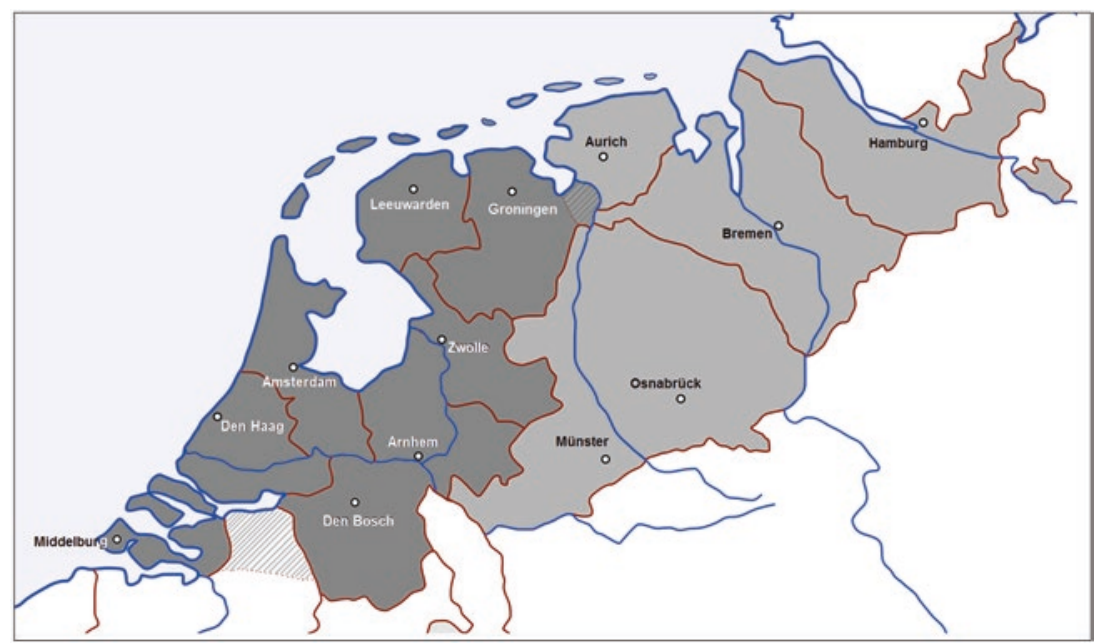

Map 1.2 'Dutch' and 'German' departments as defined in this study, with préfectures (departmental seats of government)

as inlijving/Einverleibung (incorporation) or bezetting/Besetzung (occupation). Here, I differentiate between 'conquest', 'incorporation', and 'integration'.

Firstly, conquest is characterized by a change of power, whether or not by force, making one country controlling, partially or fully, the territory of another country. This is not necessarily a definitive violation of a nation's sovereignty, since it does not mark the legal transfer of power. In the early modern period this notion largely overlapped with 'occupation', in the sense of occupatio bellica. ${ }^{57}$ As said, particularly German historians have made use of the notion of 'occupation' as analytical concept. However, I choose 'conquest' over 'occupation', firstly, because of Napoleon's frequent referrals to pays conquis and his preoccupation with droit de conquête. Secondly, many of the earlier-mentioned historians have already extensively explored the concept of occupation. And thirdly, Stuart Woolf doubts the explanatory value of 'occupation', as it does little justice to

${ }^{57}$ Peter M. R. Stirk, 'The concept of military occupation in the era of the French Revolutionary and Napoleonic Wars', Comparative Legal History 3 (2015) 64. https://doi. org/10.1080/2049677X.2015.1041726 
sincere efforts many administrators made to build a new state and society, albeit with mixed results. ${ }^{58}$

Secondly, incorporation entails the constitutional transfer of sovereignty. I favor 'incorporation' as an analytical concept to 'annexation' because of its resemblance to Dutch inlijping, and German Einverleibung. In many ways incorporation is a legal act, often an imperial decree, on an exact date. Incorporation does not imply that all state institutions are straightaway imposed on the incorporated territory, let alone that new authorities are genuinely accepted.

In contrast, integration, to complete the trichotomy, does aim to render incorporated lands integral parts of the Empire, by extending the central government's authority, and with it, implicitly or explicitly, reducing the mental distance between core and periphery. Unlike incorporation, integration was not a well-defined, single legal act, but a continuing process of molding pays conquis into pays réunies. It does so primarily through the implementation of imperial institutions and governing practices. In this perspective, Woolf speaks of Napoleonic integration as 'a model of government and administration, an updated and far more powerful version of the mainstream ideals of Enlightenment writers and the practical reforms of some Enlightenment rulers and administrators' ${ }^{59}$ Such an idea of integration implied a strong opposition between local diversity and 'modern' uniformity, which affected the policies pursued in Europe. Although Napoleonic administrators did not use the term 'modernization', they regarded themselves as the modernizing force of Europe. Their view of the modern state consisted of the concentration of the exercises of power in the hands of state servants, to the detriment of traditional, less specialized institutions. ${ }^{60}$ In other words, in this study, integration and modernization are strongly associated with the introduction of Napoleonic governance.

Obviously, historical developments are never linear and boundaries between abovementioned phases can be contested. As a matter of fact, one

\footnotetext{
${ }^{58}$ Stuart Woolf, 'Napoleon: Politics of integration?', Bibliothek des Deutschen Historischen Instituts in Rom 127 (2013) 22.

${ }^{59}$ Ibid., 23.

${ }^{60} \mathrm{John}$ Breuilly, 'Napoleonic Germany and state-formation', in: M. Rowe ed., Collaboration and resistance in Napoleonic Europe. State-formation in an age of upheaval, c.1800-1815 (Basingstoke 2003) 135-142; Michael Rowe, 'Napoleon and the 'modernisation' of Germany', in: P. Dwyer ed., Napoleon and his Empire. Europe, 1804-1814 (Basingstoke 2007) 205 .
} 
of the main conclusions of this study, as will be elaborated on in the final chapter 'Incomplete integration', is the lack of agreement between Napoleonic authorities on the timing and intensity of integration.

In sum, by proposing a comparative and (trans)regional approach to Napoleonic governance in the Netherlands and Northwest Germany, this study will hopefully fill a lacuna in the Dutch-German body of scholarly literature. Going beyond national historiographies is easier said than done, but nation-states should not be taken as the natural starting point for historical investigation. ${ }^{61}$ Of course, cross-national history entails many practical and methodological issues, yet I believe its benefits outweigh the difficulties. ${ }^{62}$ The overarching goal is to gain a better understanding of Napoleonic governance in its entirety, shedding light on the endeavor of Napoleonic France to create a modern Europe shaped in its own image.

${ }^{61}$ Peter van Dam, 'Vervlochten geschiedenis. Hoe histoire croisée de natiestaat bedwingt', Tijdschrift voor Geschiedenis 125 (2012) 96-109. https://doi.org/10.5117/ tvgesch2012.1.dam

${ }^{62}$ Jürgen Kocka's argument for the comparative method is essential reading for all academic historians. See Jürgen Kocka, 'Comparison and beyond', History and Theory 42 (2003) 39-44. 
Open Access This chapter is licensed under the terms of the Creative Commons Attribution 4.0 International License (http://creativecommons.org/licenses/by/4.0/), which permits use, sharing, adaptation, distribution and reproduction in any medium or format, as long as you give appropriate credit to the original author(s) and the source, provide a link to the Creative Commons licence and indicate if changes were made.

The images or other third party material in this chapter are included in the chapter's Creative Commons licence, unless indicated otherwise in a credit line to the material. If material is not included in the chapter's Creative Commons licence and your intended use is not permitted by statutory regulation or exceeds the permitted use, you will need to obtain permission directly from the copyright holder.

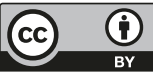

